\title{
Photochemical Behavior of Ammonia in Aqueous Suspension of $\mathrm{TiO}_{2}$
}

\author{
Ki-Min Bark, ${ }^{*}$ Ho-Suk Lee, Wan-Hyun Cho, ${ }^{\ddagger}$ and Hyoung-Ryun Park ${ }^{\circ}$ \\ Deparment of Chemistry and Research Institute of Basic Science. Chonnam National Lnwersin; Guangiu 500-757, Korea \\ "E-mail: hrparkochomamackr \\ -Department of Chemistry and Research Institute of Life Science, Gyeongsang Vational Chiversity. Chimju 660-701, Korea \\ -Department of Statistics, Chonnam National Liversin, Guangin $500-757$, Korea \\ Received Februarv 13. 2008
}

Key Words : Photochemical decomposition Ammonia. TiO_ particles. Photocatalyst, Hydrazine

Ammonia is produced in huge quantities worldwide not only by commercial chemical factories but by decaying vegetation garbage even decomposition of the other protein materials. Ammonia with foul odor causes a serious environmental pollution in the atmosphere. Therefore the decomposition of ammonia has attracted considerable attention in respect to environmental pollution of the atmosphere.

Earlier investigation on the decomposition of ammonia using a light was performed by means of radiolysis 1.2 and photolysis ${ }^{3-8}$ in the gaseous state. Ammonia molecules are incorporated into water droplets and form liquid aerosols which can range in diameter with nanoscale particle. ${ }^{9} \mathrm{Re}$ cently, we have reported on the photochemical decomposition of aqueous ammonia in the absence and presence of oxygen using $184.9 \mathrm{~nm}$ UV light. ${ }^{10}$ It was found that hydrazine was mainly produced by the dimerization of $\mathrm{NH}_{3}$ radicals and oxygen affected the formation of hydrazine. In order for a photochemical reaction to occur. reactant chemical species must absorb the light illuminated. $\mathrm{NH}_{3(\mathrm{ac}) \text {. }}$ $\mathrm{NH}_{4}^{+}$iaq. $\mathrm{OH}_{\mathrm{ar}}$ and $\mathrm{H}_{2} \mathrm{O}$ species exist in the aqueous ammonia solution. Since such chemical species have relatively strong intramolecular chemical force, a high enough energy is necessary to begin the photochemical reaction. It corresponds to vacuum UV light to break the chemical bond of such chemical species. The photochemical reaction of aqueous ammonia can not be carried out by a natural ultraviolet solar radiation on the earth's surface. because the solar energy reached on the earth's surface is the wavelength above $\lambda=314 \mathrm{~mm}$ UV light. It is necessary to use a photocatalyst to begin the photochemical decomposition of aqueous ammonia. Metal oxide such as titanium oxide and zinc oxide may be used for the purpose as a photocatalyst. It is well known that titanium oxide absorbs photons with energy. higher than its bandgap $(\sim 3.2 \mathrm{eV})$ and electronhole pairs. so called geminated form are produced. "l To our knowledge. there has been no report to date on the quantitative results for photochemical reaction of aqueous ammonia in the presence of $\mathrm{TiO}_{2}$ particles. Since the photochemical reactions are very fast. products analysis is generally used to determine the photochemical behavior in a system. The aim of this study is to present the quantitative results for the photochemical reaction of the aqueous ammonia containing $\mathrm{TiO}_{2}$ particles using $253.7 \mathrm{~nm}$ UV light and to elucidate the behavior of
$\mathrm{TiO}_{2}$ during the photochemical reaction of aqueous ammonia based on the product analysis.

\section{Experimental Section}

Lightsource and Actinometry. Irradiations were carried out at $25^{\circ} \mathrm{C}$ usinglow pressure $\mathrm{Hg}$ lamp (Osran HNS 10W/ $\mathrm{U}$ OFR). Low pressure Hg lamp is classified into two types depending on the method of its emitting wavelength: ozone generating lamp and ozonefree lamp. ': The ozonefree lamp used in this study enits only $253.7 \mathrm{~nm}$ UV light. but on the other hand ozone generating lamp enits two monochromatic lights of 184.9 and $253.7 \mathrm{~nm}$. The lamp was mounted in a quartz tube which was surrounded by the solution to be irradiated. The reaction vessel was made of Pyrex and was isolated from the lamp by means of a quartz tube. The intensity of the $253.7 \mathrm{~mm}$ light was determined by monochloroacetic acid actinometer ${ }^{13.14}$ The yield of chloride ion $\left(\mathrm{Cl}^{-}\right)$formed during the irradiation of aqueous monocluloroacetic acid was measured by spectrophotometric method The lamp intensity was found to be $5.37 \times 10^{18}$ quanta $\mathrm{mL}^{-1} \cdot \mathrm{min}^{-1}$ at $25^{\circ} \mathrm{C}$ from the known quantum yield. $\mathrm{Q}\left(\mathrm{Cl}^{-}\right)$ $=0.32 .^{3.14}$ No change in the intensity of the lamp was observed over the period of the experiment. The number of quanta. indicating the whole of emitted intensity from the lamp during the irradiation. was obtained by the multiplication of the lamp intensity by the irradiation time.

Reagents and General. Ammonium hydroxide (28\% $\mathrm{NH}_{3}$ in water. $99.99+\% \mathrm{NH}_{4} \mathrm{OH}$ ) was purchased from Aldrich Chemical $\mathrm{Co}$. and used as received. The $\mathrm{TiO}_{2}$ particles (rutile, grain size $\leq 0.06 \mathrm{~mm}$ ) were prepared according to the previous work: $\mathrm{TiO}_{2}$ (anatase. Aldrich) was first heated for $60 \mathrm{~min}$ at $1150^{\circ} \mathrm{C}$ in the presence of oxygen and then treated in $\mathrm{H}_{2}$ atmosphere at $700^{\circ} \mathrm{C}$ for $90 \mathrm{~min}$. $^{11.15} \mathrm{All}$ other chemicals employed in this work were reagent grade and used without further purification. Ammonium hỳdroxide was diluted using quadruply distilled water. which was obtained by passing distilled water through Barnstead (U.S.A.) Nonopure II deionization system, to prepare $\mathrm{NH}_{4} \mathrm{OH}$ solutions. For airfree aqueous ammonia, each of the distilled water and aqua ammonia were first deaerated by bubbling about $60 \mathrm{~min}$ with high purity argon (airliquidkorea co. $99.999 \%$ pure) and then used to prepare the 
$\mathrm{NH}_{4} \mathrm{OH}$ solutions. The same treatment is also employed to prepare the $\mathrm{NH}_{4} \mathrm{OH}$ solution saturated with $\mathrm{O}_{2}$. An aliquot of $\mathrm{TiO}_{2}$ was added in $80 \mathrm{~mL}$ of the fresh prepared aqueous anmonia solution and then irradiated using low pressure $\mathrm{Hg}$ lamp. During the irradiation, the solutions were stirred to keep the homogenous suspension and the temperature of the solutions was kept at $25^{\circ} \mathrm{C}$ using a waterbath circulater. The $\mathrm{pH}$ of the solutions was adjusted by adding $\mathrm{HClO}_{4}$ or $\mathrm{NaOH}$.Absorbance and UVspectrum were recorded on Uvikon (model 943) spectrophotometer.

Analysis. To remove the titanium oxide, the irradiated solution was first centrifuged and taken the liquid phase. It was then extracted using diethyl ether $(5 \mathrm{~mL})$. In order to obtain the MS spectra of the products in theirradiated aqueous ammonia, the extracted solution was analyzed using a Varian Saturn GCMS sy stem (DB5 capillary colunu $50 \mathrm{~m}$ $\times 0.25 \mu \mathrm{m}$. EI method) [product; $\mathrm{m} / \mathrm{z}$ (rel. intensity)] hydrazine: $17(10) .31(16) .32(100)$. Identifications and determinations were made by comparison with the fragmentation patterns of known amounts of the pure substance. The identified products from the MS spectra were reconfurmed by comparison with the retention time of the separated GC peaks of the standard chemical. which was performed by a Varian Model 3700 gas chromatography. Since the gas chromatographic method for the determination of hydrazine is less stable. the amount of hydrazine produced was determined by spectrophotometric method. ${ }^{16}$ Aliquot $(\mathrm{l} \mathrm{mL})$ of the irradiated solutions were treated with $p$-dimethylaminobenzaldehyde as a complexing reagent. The molar extinction coefficient (E) of colored complex was determined to be $74100 \mathrm{~L} \mathrm{~mol}^{-1} \mathrm{~cm}^{-1}$ at $458 \mathrm{~nm}$ in these experiments. From the statistical analysis, the relationship of the calibration curve is a strong linear relation between of the concentration of hydrazine and absorbance. The linear regression equation is $\mathrm{Y}$ (absorbance) $=0.736 \times$ (conc. of hydrazine) +0.0079 . The correlation coefficient between two components is approxintately equal to 0.9991 , implyung a very positive linear relationship. This method was interfered neither by the presence of the other nitrogencontaining compounds such as hydroxylamine nor by the $\mathrm{pH}$ values in the solution.

\section{Results and Discussion}

In order to investigate the photocataly'tic behavior of $\mathrm{TiO}_{2}$ particles, $\mathrm{NH}_{4} \mathrm{OH}$ solution containing suspension of $\mathrm{TiO}_{2}$ was irradiated with $253.7 \mathrm{~lm}$ UV light. Hydrazine was the main product duning the irradiation and any other products were not observed in this experimental condition. The fornation of hydrazine as a function of the number of quanta is presented in Figure 1. The product yield depended both on the amount of $\mathrm{TiO}_{2}$ contained in aqueous anmonia and on the number of quanta. As the anount of $\mathrm{TiO}_{2}$ increases in the solution. the yield of hydracine increases. The hydracine formation as a function of the number of quanta was not linearly proportional to an equation of the first degree. This behavior indicates that a back reaction occurred in the

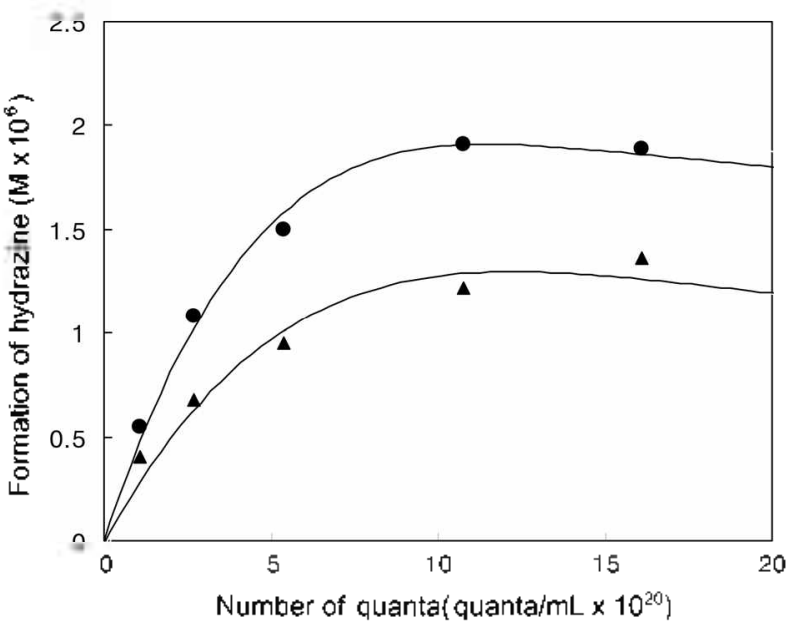

Figure 1. Fomation of hydrazine after irradiation of aerated $0.5 \mathrm{M}$ aqueous ammonia containing $\mathrm{TiO}_{2}$ as a function of the number of quantel: ( ) is $0.4 \mathrm{mg} / \mathrm{mL} ;(\Delta)$ is $0.2 \mathrm{mg} / \mathrm{mL}$.

Table 1. Initial quantum yield $(Q i)$ of hydrazine after irradiation $(\lambda$ $=253.7 \mathrm{~nm})$ of the aqueous ammonia containing TiO $(0.4 \mathrm{mg} / \mathrm{mL})$ at $25^{\circ} \mathrm{C}$

\begin{tabular}{cccc}
\hline \multirow{2}{*}{$\begin{array}{c}\text { Initial conc. of ammonia } \\
\text { (M) }\end{array}$} & \multicolumn{3}{c}{ Qi $\left(\times 10^{5}\right)$ when saturated with } \\
\cline { 2 - 4 } & $\mathrm{AI}$ & $\mathrm{Alr}$ & $\mathrm{O}_{2}$ \\
\hline 1.0 & 0.42 & 0.42 & 0.41 \\
0.5 & 0.31 & 0.30 & 0.32 \\
0.1 & 0.23 & 0.24 & 0.24 \\
\hline
\end{tabular}

system lead to the decomposition of hydrazme by an attack of the radicals formed during the photochemical reaction. It is therefore calculated the initial quantum yield $\left(\mathrm{Q}_{1}\right)$. obtained from the slope of the tangent line of the curve in Figure 1, were determined and summarized in Table 1.

There are $\mathrm{NH}_{3(\{q q)}, \mathrm{NH}_{+}^{+}(a q), \mathrm{OH}_{a q}$ and $\mathrm{H}_{2} \mathrm{O}$ chemical species in the aqueous anmonia solution. All of these chemical species did not absorb the $253.7 \mathrm{~nm}$ UV light." However. $\mathrm{T}_{1} \mathrm{O}_{2}$ particles absorb photons with energy higher than its bandgap ( $3.2 \mathrm{eV}$ ) which corresponds to a light with about $400 \mathrm{~nm}{ }^{12.17}$ In the irradiation of aqueous ammonia solution containing $\mathrm{TiO}_{2}$ particles by $253.7 \mathrm{lum}$ UV light. only $\mathrm{TiO}_{2}$ absorbed all of the light at the mitial process of the reaction. It means that the photochenical formation of hydrazine begins by the absorption of $\mathrm{T}_{1} \mathrm{O}_{2}$ particles. It is well known that the electronically excited $\mathrm{TiO}_{2}$ by the absorption of UV light is created as the geminated form on the surface of the $\mathrm{T}_{10} \mathrm{O}_{2}$ as presented in equation (1) ${ }^{12.17}$ The fact that yield of hydrazme depended on the amount of $\mathrm{TiO}_{2}$ in the aqueous anmonia supports that $\mathrm{TiO}_{2}$ played an important role in the formation of hydrazine.

$$
\mathrm{TiO}_{2} \stackrel{h v}{\longrightarrow}\left[\mathrm{TiO}_{2}\right]^{*} \longrightarrow\left(\mathrm{TiO}_{2}^{+} \cdot \mathrm{e}^{-}\right)
$$

The electronlhole pairs, so called geminated form $\left(\mathrm{TiO}_{2}^{-} \mathrm{e}^{-}\right)$ is identical with $\left(\mathrm{h}^{+} \cdot \mathrm{e}^{-}\right)$. Positive hole $\left(\mathrm{h}^{-}\right)$is acting as an oxidizing agent. The electron on the surface of the $\mathrm{TiO}_{2}$ particles can diffuse away and becomes solvated electron 
$\left(\mathrm{e}_{\mathrm{aq}}^{-}\right)$in the solvent. The positive hole $\left(\mathrm{h}^{-}\right)$can be also converted into $\mathrm{H}_{2} \mathrm{O}^{-}$and $\mathrm{NH}_{3}{ }^{+}$(aq) by the reaction with $\mathrm{H}_{2} \mathrm{O}$ and $\mathrm{NH}_{3 i a q)}$ as in reaction (2) and (3).

$$
\begin{aligned}
& \mathrm{H}_{2} \mathrm{O}+\mathrm{TiO}_{2}^{-} \longrightarrow \mathrm{H}_{2} \mathrm{O}^{+}+\mathrm{TiO}_{2} \\
& \mathrm{NH}_{3(\text { (aq) }}+\mathrm{TiO}_{2}{ }^{+} \longrightarrow \mathrm{NH}_{3}{ }_{\left({ }_{(\mathrm{q} q)}\right.}+\mathrm{TiO}_{2}
\end{aligned}
$$

The $\mathrm{H}_{2} \mathrm{O}^{+}$and $\mathrm{NH}_{3}^{-}$iagi species can react with $\mathrm{H}_{2} \mathrm{O}$. and $\mathrm{OH}$ radicals can be formed by the reaction (4) and (5). The $\mathrm{OH}$ radicals produced can attack ammonia in the solution and the $\mathrm{NH}_{2}$ radicals were formed as in reaction (6). In addition to the reaction. the $\mathrm{OH}$ radicals can also react with each other leading to hydrogen peroxide as in reaction (7). The formation of hydrazine could be. therefore, explained by the dimerization process of $\mathrm{NH}_{2}$ radicals in reaction (8).

$$
\begin{aligned}
& \mathrm{H}_{2} \mathrm{O}^{-}+\mathrm{H}_{2} \mathrm{O} \longrightarrow \mathrm{H}_{3} \mathrm{O}^{-}+\mathrm{OH}
\end{aligned}
$$

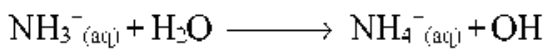

$$
\begin{aligned}
& \mathrm{NH}_{3(\text { aq })}+\mathrm{OH} \longrightarrow \mathrm{NH}_{2}+\mathrm{H}_{2} \mathrm{O}\left(k=3.6 \times 10^{7} \mathrm{M}^{-1} \mathrm{~s}^{-1}\right)^{18} \\
& \mathrm{OH}+\mathrm{OH} \longrightarrow \mathrm{H}_{2} \mathrm{O}_{2}\left(k=5.0 \times 10^{5} \mathrm{M}^{-1} \mathrm{~s}^{-1}\right)^{19} \\
& 2 \cdot \mathrm{NH}_{2} \longrightarrow \mathrm{N}_{2} \mathrm{H}_{4}
\end{aligned}
$$

In addition to positive hole $\left(h^{-}\right)$. the solvated electron $\left(\mathrm{e}_{\mathrm{aq}}{ }^{-}\right)$on the surface of the electronically excited $\mathrm{TiO}_{2}$ particles is also able to react with hy'dronium ion $\left(\mathrm{H}^{-}{ }_{\mathrm{au}}\right)$ as in reaction (9). The hydrogen atom produced by the reaction (9) can attack ammonia and more $\mathrm{NH}_{2}$ radicals thereby produced as in reaction $(10)$.

$\mathrm{e}_{\mathrm{aq}}{ }^{-}+\mathrm{H}^{+}{ }_{\mathrm{aq}} \longrightarrow \mathrm{H}$

$\mathrm{NH}_{3, a \mathrm{aq})}+\mathrm{H} \longrightarrow \mathrm{NH}_{2}+\mathrm{H}_{2}\left(k=1.1 \times 10^{8} \mathrm{M}^{-1} \mathrm{~s}^{-1}\right)^{2}$

If there is oxygen in the aqueous ammonia solution. the hydrogen atom produced by the reaction (9) can also react with oxygen molecule very fast and yield hydrogen peroxide radicals as in reaction (11). Because the reactions (9) and (10) are in competition, the photochemical formation of hydrazine diminishes in the presence of oxygen.

$$
\mathrm{H}+\mathrm{O}_{2} \longrightarrow \mathrm{HO}_{2}\left(k=2.5 \times 10^{101} \mathrm{M}^{-1} \mathrm{~s}^{-1}\right)^{21}
$$

However. the formation of hydrazine is independent of the presence of oxygen in the irradiation of aqueous ammonia as shown in Table 1. From the result. we conclude that hydrogen atom was not formed in the irradiation of aqueous ammonia containing titanium oxide. The hydronium ion produced by reaction (4) does not react with solvated electron but combined with ammonia molecule very rapidly' as in reaction (12) in this experimental condition.

$$
\mathrm{NH}_{3 i \mathrm{aq})}+\mathrm{H}_{\text {aq }}^{+} \longrightarrow \mathrm{NH}_{4}^{-}{ }^{-} \text {(aq) }
$$

Actually. most of anmonia existed as anmonium ion in acidic aqueous solution. To test that anmonium ion takes also part in the formation of hydrazine. the photochemical reaction of $0.5 \mathrm{M} \mathrm{NH}_{4} \mathrm{OH}$ containing suspension of $\mathrm{TiO}_{2}$ $(0.4 \mathrm{mg} / \mathrm{mL})$ has been carried out as a function of $\mathrm{pH}$ values in the solution. The formation of hydrazine was not detected in acidic solution. but in basic solution as in Figure 2. It

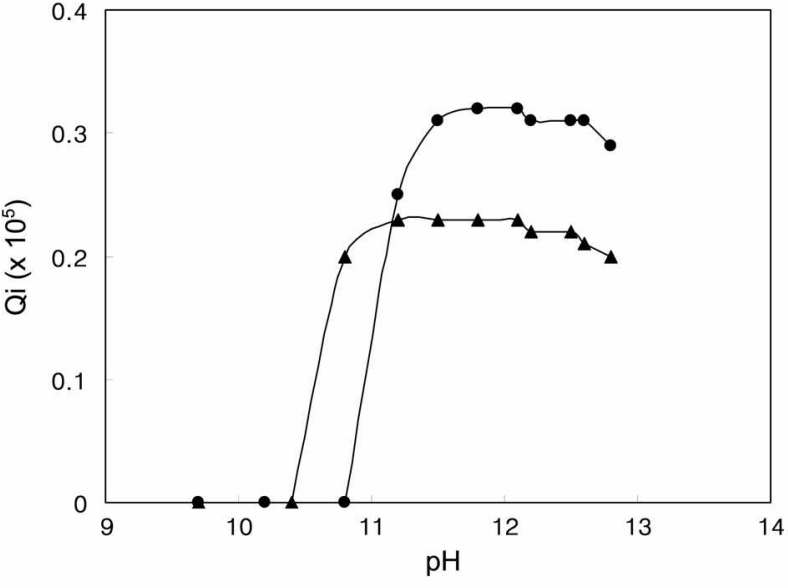

Figure 2. Initial quantum yield (Qi) of hydrazine atter irradiation of the aerated aqueous ammonia containing $\mathrm{TiO}_{2}(0.4 \mathrm{mg} / \mathrm{mL})$ as a function of the $\mathrm{pH}$ values in the solution: (O) is $0.5 \mathrm{M} \mathrm{NH} \mathrm{NH}_{+}$ (4) is $0.1 \mathrm{M} \mathrm{NH}\lrcorner \mathrm{OH}$.

suggests that hydrazine was not produced from anmonium ion but from neutral ammonia molecule. This result is quite similar to our previous result $?^{2 ?}$

The photochemical formation of hydrazine is also depended of the amount of ammonia in the solution. As shown in Table 1 , the initial quantum yield of hydrazine increased as the contents of ammonia increased in the reactant solution. Since hydrazine is only produced by the dimerization process of $\mathrm{NH}_{2}$ radicals in the experimental system, their amount is important to produce hydrazine. If $\mathrm{NH}_{2}$ radicals were formed only by the attack of $\mathrm{OH}$ radicals as in reaction (6), the initial quantum yields of hydrazine have nearly same value regardless of the initial concentration of ammonia. However. the fact that the yield of lydrazine depended on the initial concentration of ammonia supports that ammonia is also contributed to the formation of hydrazine. Because the reactions (6) and (7) are in competition. the $\mathrm{OH}$ radicals less attack the $\mathrm{NH}_{3}$ molecules in the irradiation of dilute aqueous anmonia than in that of concentrated ammonia. leading to lower yield of hydrazine. However. $\mathrm{H}_{2} \mathrm{O}^{-}$and

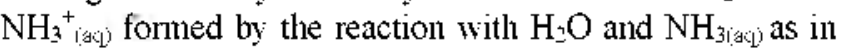
reaction (2) and (3) can not only react with $\mathrm{H}_{2} \mathrm{O}$ but with $\mathrm{NH}_{3 \text { iaci }}$ as in reactions (13) and (14). It was reported that the rate constant for the reaction (14) was very fast in the gas phase. ${ }^{23}$ This result supports that the reaction (13) and (14) could be happen on the surface of $\mathrm{TiO}_{2}$ particles in the irradiation of aqueous ammonia solution. The reaction probability for the reactions (13) and (14) increases in higher concentration of aqueous anmonia solution and more $\mathrm{NH}_{2}$ radicals thereby produced. This is a reason why hydrazine gives the higher yield with increasing the concentration of anımonia.

$$
\begin{aligned}
& \mathrm{H}_{2} \mathrm{O}^{+}+\mathrm{NH}_{2} \longrightarrow \mathrm{H}_{2} \mathrm{O}^{+}+\mathrm{NH}_{2} \\
& \mathrm{NH}_{3}^{-} \text {(aq) }+\mathrm{NH}_{3} \longrightarrow \mathrm{NH}_{4}^{-} \text {(aq) }+\mathrm{NH}_{2}\left(k=9.6 \times 10^{11} \mathrm{M}^{-1} \mathrm{~s}^{-1}\right)^{23}
\end{aligned}
$$


In conclusion. $\mathrm{TiO}_{2}$ particle was a good photocatalyst and hydrazine was produced mainly during the irradiation of the $\mathrm{NH}_{4} \mathrm{OH}$ solution containing suspension of $\mathrm{TiO}_{2}$ using 253.7 InI UV light. The photochemical reaction was only begun by the light energy absorption of $\mathrm{TiO}_{2}$ particles in the experimental conditions. Hydrazine was produced by the dimerization process of the $\mathrm{NH}_{2}$ radicals. The yield of hydrazine depended both on the amount of $\mathrm{TiO}_{2}$ contained in aqueous ammonia and on the number of quanta. The $\mathrm{OH}$ radicals formed by the reaction of $\mathrm{H}_{2} \mathrm{O}$ with positive hole $\left(\mathrm{h}^{+}\right)$on the surface of the electronically excited $\mathrm{TiO}_{2}$ particles take part mainly in the decomposition process of anmonia leading to the formation of $\mathrm{NH}_{2}$ radicals. In addition to this, $\mathrm{NH}_{3}$ molecule is also reacted with positive hole $\left(\mathrm{h}^{+}\right)$on the surface of the $\mathrm{TiO}_{2}$ particles and converted into $\mathrm{NH}_{2}$ radicals. Thus, more hydrazine is produced with increasing the concentration of ammonia. The formation of hydrazine is independent on the presence of oxygen in the irradiation of aqueous anmonia. The formation of hydrazine was not detected in acidic solution and its formation was detected only in basic solution (at $\mathrm{pH}>10$ ). It indicates that hydrazine was formed from neutral ammonia molecule rather than from ammonium ion.

Acknowledgments. This study was financially supported by research fund of Chonnam National University in 2006.

\section{References}

1. Burtt, B. P. Zahlan. A. B. J. Chem. Phys. 1957. 26,846.
2. Willis. C.: Boyd. A. W. Int, J. Radiat. Phws Chent. 1976. 8. 71.

3. Getofi. N. Z. Natutforsch 1964. 19(4). 303.

4. Haak. H. K.: Stulu. F. J. Ph.s. Chent 1984. 88.2201.

5. Ni. T.; Yu. S.: Ma, X.: Kong. F. Chem. Phus. Lett. 1986. 126. 413.

6. Kenner. R. D; Browarzik, R. K.: Stuhl, F. Chem. Phus. 1988, 121. 457.

7. Beach. D. B.: Jasinski. T. M. J. Phs Chem. 1990. 94. 3019

8. Ogura. K.: Migita. C. T.: Nakayama. M. J. Chem. Soc.. Foraday Trans 1990. 86.2565.

9. Christen, P. S.: Wedel, S.; Livbjerg, H. d. Aerosol Science 1992. 23(1). 261.

10. Park, H. R.; Kim. H. J.: Sung. A. Y. Bull. Korean Chem. Soc. 1996. $17(9) .798$

11. Park. H. R.: Li. G. Getoff. N. Z. Naturforsch. 1988. $+3 a .1126$.

12. Technical information for Osram HNS UVC lamps. Osram Co. 1990.

13. Smith, R. N.: Leighton, P. A.: Leighton. W. G. J. Am. Cham. Soc. 1939.61 .

14. NeumnannSpallart. M:: Getoff. N. Montatkh. Chem. 1975. 106. 1359.

15. Hartig. K. T.: Getoffi. N. Hht. J. Hydrogen Energy 1986. $1 /(12)$. 773 .

16. Watt, G. W.; Chrisp, J. D. Anal. Chem. 1952, 24. 2006.

17. Mozzanega, H: Herrmann. J. M.; Pichat, P. J. Phys. Chem 1979. $83(17) .2251$

18. Lati. T.: Meyerstein. D. horg. Chem. 1972. H. 2393

19. Pagsberg. P. B.: Christensen. H.: Rabani. T.: Nilson. G.: Fenger. J.: Nielsen, S. O. J. Phus. Chem. 1969.73. 1029.

20. Farhaziz, A. M.: Ross, A. B. Selected Specific Rates of Reaction of Transients from Water in Aqueous Solution. II. Hydrogen Atom; National Bureau of Standards: Washington. D. C.. 1975: p 12.

21. Willson. R. L. J. Chent. Soc. Faradar Trans. 1971. 67. 3608.

22. Park. H. R.: Kim. H. T.: Lee. H. C. Bull Korean Chem. Soc. 1997. $18(2) .226$

23. Ryan. K. R. J. Chem. Phus. 1970. 53, 3844. 